\title{
'n Ontdekkingsreis deur die wêreld van Bybelvertaling
}

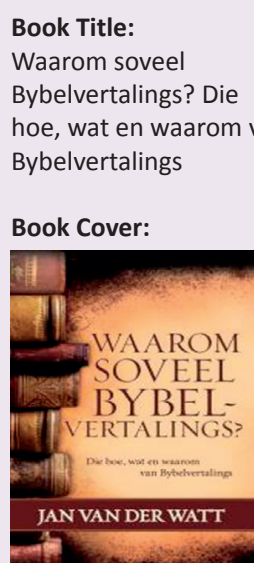

Author:

Jan van der Watt

ISBN:

978-1-4316-1019-8

\section{Publisher:}

Christelike

Uitgewersmaatskappy, 2014 R99.95*

*Book price at time of review

$\square$

Review Title:

'n Ontdekkingsreis deur die wêreld van Bybelvertaling

Reviewer:

Hennie Goede ${ }^{1}$

\section{Affiliation:}

${ }^{1}$ Unit for Reformed Theology and the development of the South African society, Faculty of Theology, North-West University, Potchefstroom Campus, South Africa

Email:

henniegoede@telkomsa.net

Postal address:

PO Box 76346,

Lynnwoodridge 0040,

South Africa

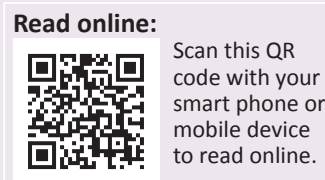

Bybelvertaling lê in die hart van kerkwees, en daarom het gelowiges dikwels baie definitiewe en uitgesproke standpunte daaroor. Elke nuwe Bybelvertaling bring gesprekke en meningsverskille hieroor weer op die voorgrond (soos nou weer die geval is met die Bybelgenootskap van SuidAfrika se vertalingsprojek Die Bybel: 'n Direkte Vertaling). Hierdie publikasie van Jan van der Watt is daarom besonder relevant. Van der Watt is tans professor by Radboud Universiteit in Nijmegen, Nederland sowel as buitengewone professor in Nuwe Testament aan die Noordwes-Universiteit, Potchefstroom. Hy is 'n ervare navorser en Bybelvertaler wat al by verskeie vertalingsprojekte soos die Boodskap en die Bybel vir Kinders betrokke was. Oor sy bevoegdheid om oor die onderwerp te skryf, is daar dus geen twyfel nie.

Met hierdie publikasie poog Van der Watt om die vrae in gelowiges se gemoed rondom Bybelvertaling te beantwoord. Die hooftitel, 'Waarom soveel Bybelvertalings?', vat die vrae saam. As gelowige word ' $n$ mens in Afrikaans met sewe verskillende vertalings (konserwatief getel) gekonfronteer, en 'n agste is in die proses van vertaling. Dit laat die vraag, naamlik watter een van die groot verskeidenheid vertalings dan nou reg is, onwillekeurig ontstaan.Verder verteenwoordig die subtitel, 'Die hoe, wat en waarom van Bybelvertaling', 'n verskeidenheid vrae wat uit die hooftitel voortvloei. Dit sluit vrae in soos: Wat gebruik jy as grondteks?; Hoe vertaal mens?; Wat is die doel van vertaling?; en Hoe bepaal mens die akkuraatheid van vertaling? Van der Watt bespreek al hierdie aspekte en nog meer om sodoende 'n geheel van die vertalingsproses weer te gee en om dít wat vir nie-deskundiges dalk obskuur mag voorkom, deursigtig te maak.

Die boek word in drie hoofdele verdeel: Deel 1 bespreek die teks agter die Bybelvertaling (die grondteks) en die wetenskap van tekskritiek wat die bepaling van die grondteks ten doel het. Die fokus is op die Griekse teks van die Nuwe Testament, hoewel dieselfde beginsels ook op die Hebreeus of Aramese teks van die Ou Testament van toepassing is. Met dít as agtergrond, dui Van der Watt oortuigend aan hoekom daar verskille in vertalings voorkom. Hy antwoord ook op kritiek op die grondteks wat vir meer onlangse vertalings gebruik is. Deel 2 fokus op verskillende teorieë wat oor Bybelvertaling bestaan wat dan ook verskille in vertalings tot gevolg het. Van der Watt gee 'n goeie verduideliking vir die kontinuum van die letterlike (woord vir woord) tot die vrye (gedagte vir gedagte) teorieë met die dinamies-ekwivalente iewers in die middel. Hy wys ook op die sterk- en swakpunte van elke benadering. In deel 3 vra die skrywer waarom dit so belangrik is dat die Bybel akkuraat vertaal moet word. In die lig van die ontstaansgeskiedenis van die Nuwe Testament as kanon, kom Van der Watt tot die gevolgtrekking dat die Bybel as Woord en God, en daarom as die lig op elke gelowige se pad, akkuraat vertaal moet word, met inagneming van die benadering en doel van elke vertaling.

Om hierdie wye veld met sy verskillende subvelde in slegs 184 bladsye só te beskryf dat die niedeskundige leser dit kan verstaan, is 'n moeilike taak. Navorsers spandeer immers'n hele loopbaan aan een klein aspek van die geheel. Volgens my slaag Van der Watt tog daarin om 'n geheelbeeld te gee wat vir elke leser sin sal maak, en eenvoudiger antwoorde op ingewikkelde vrae sal verskaf.

Die publikasie se redigering is nie altyd na wense nie. Plek-plek is daar onnodige herhaling en soms is die Griekse woorde verwarrend. Dieselfde voorbeelde word herhaaldelik gebruik, hoewel dit op sigself sekerlik ' $n$ aanduiding is dat die vertalingsprobleme in die Bybel nie so groot en diepgaande is soos soms voorgegee word nie. Tog beveel ek Waarom soveel Bybelvertalings? Die hoe, wat en waarom van Bybelvertalings met vrymoedigheid aan vir elke gelowige op soek na antwoorde op die tipiese vrae in verband met Bybelvertaling, veral in die lig van die nuwe Afrikaanse direkte vertaling wat reeds gedeeltelik in proefvertalings beskikbaar is (http:// www.bybeldirektevertaling.co.za). Hierdie publikasie lewer 'n groot en onmisbare bydrae tot die openbare Bybelvertalingsdebat in ons kerke omdat dit lesers op 'n ontdekkingsreis deur die wêreld van Bybelvertaling meevoer.

How to cite this book review: Goede, H., 2015, "n Ontdekkingsreis deur die wêreld van Bybelvertaling', In die Skriflig 49(1), Art. \#1984, 1 page. http://dx.doi.org/10.4102/ids.v49i1.1984

Copyright: @ 2015. The Authors. Licensee: AOSIS OpenJournals. This work is licensed under the Creative Commons Attribution License. 